\title{
The Impact of Corporate Governance on Chinese Firms Performance: A Board Structure Perspective
}

\author{
Hanan Mohamed Abdelhafiez Mohamed* \\ 290741015@qq.com \\ Xiaoyan Zhou \\ njulily@126.com \\ Muhammad Amin \\ pakamin22@yahoo.com \\ UIBE Business School \\ University of International Business and Economics, Beijing, China
}

\begin{abstract}
Since the last few years, corporate governance emerged as a highly important research topic in China. The major objective of this paper is to empirically pinpoint the impact of corporate governance on the performance of Chinese listed firms using different variables. To narrowing down the topic, we included board structure variables to evaluate the firm performance. We have investigated the data of Chinese companies listed on Shanghai stock exchange and Shenzhen stock exchange from 2008 to 2011. There are 6981 observations used for regression and spearman correlation coefficient analysis. The variables used in this research paper to measure firm performance included return on equity, return on invested capital and Tobin's $Q$ while corporate governance variables were board size and board independence. In a broader perspective, empirical results clearly indicate that the board size has significant negative effects on firm performance. On the other hand, the board independence has overall significant positive effects on firm performance. These findings bear board implications in corporate governance, and thus could be helpful in improving the governance, performance and productivity of the firms to comply with the challenges posed by competing firms in the end.
\end{abstract}

Keywords: corporate governance, board structure, firm performance

\section{INTRODUCTION}

In this so-called global village, corporate governance is an important factor for sustainable development of firms. It is a systematic set of management strategies that determine the capital investment and ensure investors get a fair return on their investment as argued by [1]. There are many forms and definitions of corporate governance. For instance, according to [2], it is "the system by which companies are directed and controlled". It is sort of regulatory mechanisms of controlling labor, market, capital and organization, which ultimately determine success of new enterprises in the context of welfare of firms and related stakeholders as stated [3]. With the advent of industrialization across globe, corporate governance has witnessed a great evolution and revolution in it as described by [4]. The corporate governance system of a country is a part of wider institutional structure that oversee the relationship between executives, which control the organization's resources, and social and economic activities of stakeholders who possess strong interest in the firm's activities argued by [5].

The governance structure of the Chinese listed firms is very substandard in quality due to the unrestrained managerial discretion, lower level of outsider's safe conduct and unsatisfactory transparency issues [6]. For instance, despite the wonderful reforms in governing body of Chinese state owned enterprises (SOEs), there is still a big vacuum to fill in. However, in their study of Chinese firms, [6] found that the firms with well-established corporate governance structure are related with the higher stock market value.

Chinese securities regulatory commission is the only governing body in China that is legally bound to provide assistance and license regarding the listing issuing choices of Chinese firms on two local 
stock exchanges namely Shanghai stock exchange and Shenzhen stock exchange [7]. In the late 1990s the Shanghai stock exchange was came into being. Meanwhile the Shenzhen stock exchange was establish in the beginning of 1991 in reciprocal manner [8]. During that time period (1991) the first Chinese firm went public [8].

Particularly, board structure plays multifaceted role in the corporate governance that leads to the greater financial performance of the firms and consequently increased the wealth of the investors [9]. On the other hand, due to the weak governing structure in emerging economies, firms have less financial incentives to perform better [10]. For example, [11] describes that the increase in board size up to a certain level is detrimental to the firm and could lead to the poor performance.

The remaining structure of this research paper is as follows. Section 2 addresses the literature review. Section 3 discusses the data and research methods. Section 4 discusses the hypothesis development. Section 5 briefly summarizes the empirical analysis. Finally, section 6 provides the brief discussion and conclusions of this research paper.

\section{LITERATURE REVIEW}

\subsection{Board Size}

Agency theory describes the principle agent relationship between managers and shareholders where the conflicting interests between the both parties are prevalent in the modern organizations [12]. Previous research describe that the firms that are efficaciously governed by the corporate actors delineate the irrefutable perception in front of investment society [13]. In the context of board structure, the firm performance goes higher with the large size of the corporate board as stated by [14].

There is a burgeoning research on the size of the corporate board that show the optimistic relations of the board size that evaluate the higher level of firm performance [14], [15]. There are many reasons to keep larger board size such as, for instance, having more directors on the board provide the diversity of knowledge and skills to the organization [16]. Most of the directors possibly have different abilities and expertise regarding corporate affairs [17]. However, the large board members have more access to the bigger market information than few board members [16].

In addition to the previous research, some scholars of corporate governance provide manifestation of larger corporate board size that can, more or less, overcome the discretionary dominance of the executives in terms of making corporate decisions [14]. Contrarily, the other stream of research provides the evidence that the firms with larger board are poorly governed [18]. They emphasize that the firms with smaller board size are more effective than the firms with larger board size. The smaller board size is beneficial to the firm in terms of reducing cost of lack of effective communication and decision-making as compared to the larger corporate board size [18].

The leading scholars in corporate governance propose that the board size should not be more than 8 or 9 members [19]. According to [20] the larger board size is beneficial for the large firms. Additionally, it has positive relationship with the performance of larger firms. This implies that the larger firms should have larger board size to perform better. On the other hand, [21] describe that the larger board size is beneficial up to a certain point where it get worse by means of lack of effectiveness in decision making. This implies that the larger board size has diminishing benefits to the firm and it starts declining when it crossed a certain point.

There are two important functions that the board of directors performs namely the advisory function and the monitoring function [22]. In their advisory function board provides valuable information to the manager on the basis of their expertise and skills [23]. The larger board size provides many clouts to the firm such as the abundance of useful information collectively at the same time could help the higher level of firm performance [16]. Meanwhile, in China the firm's board size ranges from five to nineteen members [24]. On the other hand the board of supervisor mush have minimum limit of three members in each of the firm that got listed [24].

\subsection{Board Independence}

Independent board plays a vital role of monitoring the managerial actions in the firm by representing firm's stockholders [24]. By defining board independence, [25] states that the members of the board should supervise and give advise freely to the corporate executives in order to effectively monitor the 
decision making activities of the manager in the day to day business settings. They have many benefits to enhance the disclosure level of the firm and have ability to influence it [11]. In investors point of view board independence is quite important provided the skills and abilities that the board possesses [26]. It can provide very important clue to outsiders that the firm is well governed and able to achieve great financial performance [26].

Firms having influential board structure laden of independent directors said to be well managed and effectively controlled [9]. Outside directors have logically more incentives to perform well as an effective monitor to safeguard their prestige while making independently corporate decisions [26]. Previously, the studies have been done on U.K. and U.S.A. corporate governance unveil that the independent directors act as a monitor of the executives [27]. An American research on corporate governance shows that the independent board has reasonable impact on board decisions in terms of termination of non performing executives [26].

Board structure of the firms has higher board independence have less fraudulent interference in the financial statements while board having dominant managerial discretion is more likely to face litigation charges [24]. A U.K. study unveils that the firms with higher level of outsider directorship are stricter to disclose the financial reports [27]. More specifically, there is a research that empirically shows investors give higher value and premium to the firm that has independent board of directors [25].

There was a dearth of requirement of independent directors for Chinese listed firms in China since 2001[8]. Nevertheless, there had been hardly a few numbers of firms that had independent board of directors [28]. In the mainland, only little number of independent boards of directors has consecration. That was absolutely glazing over and storming state of affairs of the level of smaller size of board independence in Chinese firms [8].

The smaller number of independent board of directors depicts the prevalence of insider ownership style in the firm [10]. Insiders do not allow the scrutinizing of the business because they have their own concerns and interests in the firm. This was the main reason to make rules for having independent directors [29]. The purpose of this decision was to assure the accountability and fairness of the financial information disclosure [30]. In the recent period, it is compulsory that the each firm that got listed must have twenty five percent of independent board of directors argued by [9]. In China at least $1 / 3$ of the board members should be independent as stated in the Chinese law [6].

\section{DATA AND RESEARCH METHODS}

\subsection{Data Source and Sampling}

The sample for this study consists of all firms listed on the Shanghai stock exchange and the Shenzhen stock exchange. The type of data is secondary data consisting of four years from 2008 to 2011. The data has been collected from Chinese stock market \& accounting research database. Initially the data set was consisting of 13 industries by quarterly, semi-annually, and annually. We excluded all the banking, finance and insurance companies from the data set and used only A stock shares.

\subsection{Processes and Procedures}

The features of the data sample is both the time series and cross sectional data, therefore, the panel data is being employed to analyzed data to test the correlation and coefficient relationship between the variables that are used in this study by using spearman model while regression analysis is also applied.

\subsection{Variable Selection}

In this study, wehave included corporate governance, firm evaluation or firm performance variables and controlling variables to test the hypothesis such as return on equity, return on invested capital and Tobin's q to evaluate the firm performance while board size, board independence are used as corporate governance variables. To controll the modelweused leverage (debt to equity ratio), total asset as a proxy to firm size (log asset to get minmium beta values) and one dummy variable of ownership style whether the firm is state owned enterprise (1) or private firm (0). 


\section{HYPOTHESIS DEVELOPMENT}

\subsection{Corporate Board Size}

The firms' which have larger board size make it too difficult the interaction among members and lead to delays in corporate decision makings consequently have negative impressions on the firm performance. Previous studies found that the board size has negative impacts on firm performance. In line with the previous studies we have design the similar hypothesis:

H1: Ceteris paribus, there is a negative relationship between corporate board size and firm performance.

\subsection{Corporate Board Independence}

There is a voluminous research on corporate board independence show the significant positive relationship between board independence and firm performance both in finance and management studies. Previous research delineate that the higher ratio of independent corporate board of directors in the firm has positive impacts and the performance of the firm goes higher. Again, in line with the previous studies we have developed the following hypothesis:

$\mathrm{H} 2$ : Ceteris paribus, there is a positive relationship between corporate board independence and firm performance.

Table1. Description of the Variables

\begin{tabular}{|c|c|}
\hline Variable Name & Description \\
\hline ROE & $\begin{array}{l}\text { Return on equity is a performance variable calculated as net income divided by } \\
\text { shareholder's equity. }\end{array}$ \\
\hline ROCE & $\begin{array}{l}\text { Return on invested capital is a performance variable calculated as earnings before } \\
\text { interest and taxes (EBIT) divided by invested capital or capital employed. }\end{array}$ \\
\hline Tobin's Q & $\begin{array}{l}\text { Tobin's q is very important performance variable measure calculated as = total } \\
\text { market value of firm's assets divided by the book value of firm's assets while } \\
\text { market value is equal to the book value of assets plus market value of common stock } \\
\text { minus book value of common stock }\end{array}$ \\
\hline Corporate Board Size & $\begin{array}{l}\text { Corporate Board Size is the variable of corporate governance that means the number } \\
\text { of board of directors in the firm. }\end{array}$ \\
\hline $\begin{array}{l}\text { Corporate } \\
\text { Board Independence }\end{array}$ & $\begin{array}{l}\text { Corporate board independence shows the proportion of boards of directors that are } \\
\text { being independent or proportion of outside directors on the company's board. }\end{array}$ \\
\hline Leverage & Leverage is a control variable measure as the $=$ total debt divided by total equity. \\
\hline Log Asset & $\begin{array}{l}\text { Log asset is the natural logarithm of total assets of the firm proxies as the firm's size } \\
\text { used as controlling variable. }\end{array}$ \\
\hline Dummy Own & $\begin{array}{l}\text { Ownership is used as a controlling dummy variable in case of state owned enterprise } \\
\text { is } 1 \text { otherwise } 0 \text {. }\end{array}$ \\
\hline
\end{tabular}

ROE: return on equity

ROCE: return on capital employed

\section{EMPIRICAL ANALYSIS}

\subsection{Econometric Model Estimation}

After the development of hypothesis on the basis of given theory, this study develops a regression model for testing the empirical analysis. Following is the model of corporate board structure and firm performance:

$$
\begin{aligned}
& R O E=\beta_{0}+\beta_{1} B S+\beta_{2} B I N D+\beta_{3} \text { leverage }+\beta_{4} \text { LNasset }+\beta_{5} \text { Down }+\epsilon \\
& R O C E=\beta_{0}+\beta_{1} B S+\beta_{2} B I N D+\beta_{3} \text { leverage }+\beta_{4} \text { LNasset }+\beta_{5} \text { Down }+\epsilon \\
& \text { Tobins' } Q=\beta_{0}+\beta_{1} B S+\beta_{2} B I N D+\beta_{3} \text { leverage }+\beta_{4} \text { LNasset }+\beta_{5} \text { Down }+\epsilon \\
& \text { Where }
\end{aligned}
$$

$\mathrm{ROE}=$ return on equity

ROCE $=$ return on capital employed

$\mathrm{BS}=$ board size

BIND $=$ board independence

Down: dummy ownership (1 state owned, 0 otherwise) 


\subsection{Statistical Descriptions}

In this paper, we have taken ROE, ROCE and Tobin's q used as the proxies to measure the accounting performance, market performance and firm evaluation. Table II reveals that the average of return on equity is $5.56 \%$ percent with the standard deviation of 2.96 percent. The average of return on capital employed is $68.63 \%$ percent, which is very high with the standard deviation of 1.26 percent. The mean value of Tobin's q is 6.32. As shown in the descriptive statistic:

Table2. Descriptive Statistics

\begin{tabular}{|l|l|l|l|l|l|}
\hline Variables & Obs. & Mean & Std. Dev. & Min & Max \\
\hline ROE & 6981 & .0556327 & .0296174 & -.37901 & 0.775165 \\
\hline ROCE & 6981 & .686341 & .0126492 & .079943 & 0.6866426 \\
\hline Tobin's Q & 6981 & 6.320654 & 3.038997 & -7.669285 & 182.8312 \\
\hline Board size & 6981 & 9.157571 & 1.967307 & 4 & 20 \\
\hline Board Ind. & 6981 & 3.355573 & .3197021 & 1 & 8 \\
\hline Leverage & 6981 & .1694052 & .0450256 & .000015 & 1.113079 \\
\hline LN Asset & 6981 & 10.31146 & .6705079 & 6.127123 & 13.18968 \\
\hline Down & 6981 & .8991548 & .3011451 & 0 & 1 \\
\hline
\end{tabular}

ROE: return on equity

ROCE: return on capital employed

$L N$ asset: natural log of total assets

Board Ind.: board independence

Down: dummy ownership (1 state owned, 0 otherwise)

\subsection{Regression Analysis}

Regression results have presented in table III. To examine the relation between performance variables and governance variables we run regression analysis in STATA 12. Overall, this model is significant in relations to variables applied. The board size of the firm has significant negative relationship with respect to the return on capital employed. One the other hand board size is also showing negatively significant relationship with Tobin's q.

The corporate board independence is negatively significant with respect to the return on capital employed. However, the corporate board independence has significant positive relationship on the return on equity. Meanwhile, meanwhile the corporate board independence has insignificant relationship with Tobin's q.

Table3. Regression Analysis

\begin{tabular}{|l|l|l|l|}
\hline Variables & ROCE & ROE & Tobin's Q \\
\hline Board size & $-0.0001369^{* * *}$ & $0.0004818^{* * *}$ & $-0.0584355^{*}$ \\
& $(0.0000828)$ & $(0.0001804)$ & $(0.0199341)$ \\
\hline Board Ind. & $-0.0021779^{* * * *}$ & $0.0334267^{* *}$ & 0.2389794 \\
& $(0.0005164)$ & $(0.0011245)$ & $(0.1242741)$ \\
\hline Leverage & $0.008852^{* * *}$ & $-0.0766609^{*}$ & -0.1385472 \\
& $(0.0034182)$ & $(0.0074429)$ & $(0.8225518)$ \\
\hline Logasset & $0.0008462^{* * *}$ & $0.0006317^{* * *}$ & -0.1110966 \\
& $(0.0002311)$ & $(0.0005033)$ & $(.0556187)$ \\
\hline Ownership & $-0.0004825^{* * *}$ & $-0.0012025^{* * *}$ & 0.1912256 \\
& $(0.0005045)$ & $(0.0010986)$ & $0.1214101)$ \\
\hline MSE & 0.01262 & 0.02747 & 3.0362 \\
\hline P>f & 0.0000 & 0.0000 & 0.0033 \\
\hline $\mathrm{R}^{2}$ & 0.0057 & 0.1402 & 0.0025 \\
\hline Observations & 6981 & 6981 & 6981 \\
\hline
\end{tabular}

Level of significance at 1\%,5\%,10\% are denoted with ***,**, * respectively while S.E. are in parentheses.

ROE: return on equity

ROCE: return on capital employed

LN asset: natural log of total assets

Board Ind.: board independence 


\subsection{Correlations and Coefficient Analysis}

Table 4 describes the variables of the matrix of Spearman Correlation coefficient. Overall, this model is showing the significant relationship between variables with some exceptions. Return on equity (ROE) and return on capital employed are significantly related because of the same variable measures are used in the different time periods.

Table4. Spearman Correlation Coefficient

\begin{tabular}{|l|l|l|l|l|l|l|l|l|}
\hline Variables & ROE & ROCE & $\begin{array}{l}\text { Tobin's } \\
\text { Q }\end{array}$ & $\begin{array}{l}\text { Board } \\
\text { Size }\end{array}$ & $\begin{array}{l}\text { Board } \\
\text { Ind. }\end{array}$ & Leverage & $\begin{array}{l}\text { LN } \\
\text { Asset }\end{array}$ & $\begin{array}{l}\text { Owner- } \\
\text { ship }\end{array}$ \\
\hline ROE & 1.0000 & & & & & & & \\
\hline ROCE & $\begin{array}{l}-0.0490 \\
* * *\end{array}$ & 1.0000 & & & & & & \\
\hline Tobin's Q & -0.0054 & $\begin{array}{l}0.0904 \\
* * *\end{array}$ & 1.0000 & & & & & \\
\hline Board Size & $\begin{array}{l}0.1142 \\
* * *\end{array}$ & $\begin{array}{l}-0.0372 \\
* * *\end{array}$ & $\begin{array}{l}-0.0261 \\
* * *\end{array}$ & 1.0000 & & & & \\
\hline Board Ind. & $\begin{array}{l}0.1839 \\
* * *\end{array}$ & $\begin{array}{l}-0.0835 \\
* * *\end{array}$ & $\begin{array}{l}0.1320 \\
* * *\end{array}$ & $\begin{array}{l}0.2220 \\
* * *\end{array}$ & 1.0000 & & \\
\hline Leverage & $\begin{array}{l}0.0161 \\
-0.0234 \\
*\end{array}$ & $\begin{array}{l}-0.0578 \\
* * *\end{array}$ & $\begin{array}{l}0.0426 \\
* * *\end{array}$ & $\begin{array}{l}0.0746 \\
* * *\end{array}$ & 1.0000 & & \\
\hline LN Asset & $\begin{array}{l}0.0243 \\
* * *\end{array}$ & $\begin{array}{l}0.0383 \\
* * *\end{array}$ & $\begin{array}{l}0.2703 \\
* * *\end{array}$ & $\begin{array}{l}0.0848 \\
* * *\end{array}$ & $\begin{array}{l}0.2246 \\
* * *\end{array}$ & $\begin{array}{l}-0.0265 \\
* * *\end{array}$ & 1.0000 & \\
\hline Ownership & $\begin{array}{l}-0.0398 \\
* * *\end{array}$ & $\begin{array}{l}-0.0080 \\
* * *\end{array}$ & $\begin{array}{l}0.0358 \\
* * *\end{array}$ & $\begin{array}{l}-0.0873 \\
* * *\end{array}$ & $\begin{array}{l}-0.0327 \\
* * *\end{array}$ & $\begin{array}{l}-0.0249 \\
* * *\end{array}$ & 0.0166 & 1.0000 \\
\hline
\end{tabular}

Level of significance at 1\%,5\%,10\% are denoted with ***, **, * respectively.

ROE: return on equity

ROCE: return on capital employed

LN asset: natural log of total assets

Board Ind.: board independence

\section{Conclusion}

The firm that have larger board size make to difficult the interaction among board members and have negative impacts on the performance of the firm. According to previous studies held by [18] and [21] find that the board size has negative effects on firm performance. In line with the previous stream of research [26], [24] board independence has significant impact on the firm performance. They describe that the higher ratio of independent directors in the firm has positive impacts and the performance of the firm goes higher. Nevertheless, most of the previous studies show that the firms, which have larger, board size has negative impacts on the performance. However, in our study we found that the board size has positive impacts on the valuation of Chinese firms with different performance measures.

As a matter of fact, the most of the previous studies discuss over the firms from capital structured market; those are usually the advanced countries like Germany, Japan, United Kingdom and United States of America. The reason of negative impacts of board size on the performance of the firm is the higher agency cost. The larger board size contains a significant amount of costs that are detrimental to the firm's growth.

Meanwhile it reduces the shareholders wealth-maximizing phenomenon. If the board size is large in numbers then it will obviously increase the number of board meetings and consequently it will create a higher cost of bigger board. One the other hand, in larger board size, it takes too much time to make decisions. According to our results, the board size has positive effects on firm performance. The board size has positive effects with respect to return on equity. This reveals that the equity holders have trust over the size of the board. Meanwhile, the size of the board has negative impacts with respect to the performance of the return on capital employed. This means that the equity holders are the original owner of the firm. They elect board of directors by themselves. Therefore, in Chinese context the larger board size has strong affiliation with the local or state level government. These can be beneficial to the firm in long run in terms of getting financial and moral incentives form government 
at the time of difficulties or distress. That is the one of the valid argument of larger board size has positive impacts on the valuation of Chinese listed firms. Finally, board independence has positive relationship with respect to the return on capital employed and negative relations with respect to return on equity capital. Meanwhile it shows insignificant relationship with Tobin's q.

\section{REFERENCES}

[1] Shleifer, Andrei, and Robert W. Vishny. (1997). A survey of corporate governance. The Journal of Finance, 52(2), 737-783.

[2] Cadbury, Adrian (1992). Report of the committee on the financial aspects of corporate governance. Vol. 1.

[3] Alawattage, Chandana, and Danture Wickramasinghe. (2004). Governance in dialects: their regimes and roles of accounting in Sri Lanka. In Fourth Asia Pacific Interdisciplinary Research in Accounting Conference, Singapore.

[4] Chowdary, Nagendra V., ed. (2003). Corporate Governance in Emerging Markets. ICFAI University.

[5] Carney, Michael, and Eric Gedajlovic. (2001). Corporate governance and firm capabilities: A comparison of managerial, alliance, and personal capitalisms. Asia Pacific Journal of Management. 18(3), 335-354.

[6] Bai, Chong-En, Qiao Liu, Joe Lu, Frank M. Song, and Junxi Zhang. (2004). Corporate governance and market valuation in China.Journal of Comparative Economics. 32(4), 599-616.

[7] Lin, Cyril. (2001). Corporatisation and corporate governance in China's economic transition. Economics of Planning. 34 (1-2), 5-35.

[8] Kato, Takao, and Cheryl Long. (2006). Executive compensation, firm performance, and corporate governance in China: Evidence from firms listed in the Shanghai and Shenzhen Stock Exchanges. Economic Development and Cultural Change. 54(4), 945-983.

[9] Jackling, Beverley, and Shireenjit Johl. (2009). Board structure and firm performance: Evidence from India's top companies. Corporate Governance: An International Review.17(4), 492-509.

[10] La Porta, Rafael, Florencio Lopez-de-Silanes, Andrei Shleifer, and Robert Vishny (2000). Investor protection and corporate governance. Journal of Financial Economics. 58(1), 3-27.

[11] Fama, Eugene F., and Michael C. Jensen. (1985). Organizational forms and investment decisions. Journal of Financial Economics. 14(1), 101-119.

[12] Jensen, Michael C., and William H. Meckling. (1979). Theory of the firm: Managerial behavior, agency costs, and ownership structure. Springer Netherlands.

[13] Gillan, Stuart L. "Recent developments in corporate governance: An overview. (2006). Journal of Corporate Finance. 12(3), 381-402.

[14] Dalton, Dan R., Catherine M. Daily, Jonathan L. Johnson, and Alan E. Ellstrand. (1999). Number of directors and financial performance: A meta-analysis. Academy of Management Journal. 42(6), 674-686.

[15] Forbes, Daniel P., and Frances J. Milliken. (1999). Cognition and corporate governance: Understanding boards of directors as strategic decision-making groups. Academy of Management Review. 24(3), 489-505.

[16] Van den Berghe, Lutgart AA, and Abigail Levrau. (2004). Evaluating boards of directors: what constitutes a good corporate board? Corporate Governance: An International Review. 12(4), 461-478.

[17] Goodstein, Jerry, Kanak Gautam, and Warren Boeker. (1994). The effects of board size and diversity on strategic change. Strategic Management Journal. 15(3), 241-250.

[18] Yermack, David. (1996). Higher market valuation of companies with a small board of directors. Journal of Financial Economics. 40(2), 185-211.

[19] Lipton, Martin, and Jay W. Lorsch. (1992). A modest proposal for improved corporate governance. The Business Lawyer. 59-77.

[20] Coles, Jeffrey L., Naveen D. Daniel, and Lalitha Naveen. (2008). Boards: Does one size fit all? Journal of Financial Economics. 87(2), 329-356. 
[21] Jensen, Michael C. (1993). The modern industrial revolution, exit, and the failure of internal control systems. The Journal of Finance. 48(3), 831-880.

[22] Raheja, Charu G. (2006). Determinants of board size and composition: A theory of corporate boards. Journal of Financial and Quantitative Analysis. 40(02), 283-306.

[23] Guest, Paul M. (2009). The impact of board size on firm performance: evidence from the UK. The European Journal of Finance. 15(4), 385-404.

[24] Rosenstein, Stuart, and Jeffrey G. Wyatt. (1997). Inside directors, board effectiveness, and shareholder wealth. Journal of Financial Economics. 44(2), 229-250.

[25] Ferrarini, Guido A., and Marilena Filippelli. (2014). Independent directors and controlling shareholders around the world. European Corporate Governance Institute (ECGI)-Law Working Paper 258.

[26] Bell, R. Greg, Curt B. Moore, and Igor Filatotchev. (2012). Strategic and institutional effects on foreign IPO performance: Examining the impact of country of origin, corporate governance, and host country effects. Journal of Business Venturing.27(2), 197-216.

[27] Roberts, John, Terry McNulty, and Philip Stiles. (2005). Beyond agency conceptions of the work of the non-executive director: Creating accountability in the boardroom. British Journal of Management. 16(1), S5-S26.

[28] Brown, Lawrence D., and Marcus L. Caylor. (2006). Corporate governance and firm valuation. Journal of Accounting and Public Policy. 25(4), 409-434.

[29] Huafang, Xiao, and Yuan Jianguo. (2007). Ownership structure, board composition and corporate voluntary disclosure: Evidence from listed companies in China. Managerial Auditing Journal. 22(6), 604-619.

[30] Kang, Yong, Lu Shi, and Elizabeth D. Brown. (2008). Chinese corporate governance: history and institutional framework. Vol. 618. Rand Corporation.

\section{AUTHOR'S BIOGRAPHY}

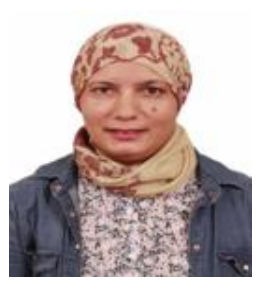

Hanan Mohamed, is a $\mathrm{PhD}$ student at Business School of University of International Business and Economics (UIBE) Beijing, China. She is from Egypt and received her Master's degree in Business Administration from UIBE in 2012. Her area of research is business management.

Xiaoyan Zhou, is an Associate Professor at Business School of University of International Business and Economics, Beijing China.

Muhammad Amin, is a PhD student at University of International Business and Economics (UIBE) Beijing, China. 